\title{
Research Paper \\ The Effectiveness of Sand Play Therapy on Anxiety and Achievement Motivation of Primary School Students
}

\author{
Saeideh Khojasteh"1 \\ 1. Assistant Professor, Department of Educational Science, Faculty of Literature and Humanity Sciences, Payame Noor University, \\ Tehran, Iran
}

Citation: Khojasteh S. The effectiveness of sand play therapy on anxiety and achievement motivation of primary school students. Quarterly Journal of Child Mental Health. 2020; 7(1): 68-80.

$\underline{\text { http://dx.doi.org/10.29252/jcmh.7.1.7 }}$

\section{A R T I C L E I N F O}

\section{Keywords:}

Sand play therapy, anxeity, acheivment motivation

Received: 23 Dec 2019 Accepted: 17 Mar 2020 Available: 30 May 2020

\section{A B S T R A C T}

Background and Purpose: Sand Play therapy is a non-verbal and symbolic way in which the learner tries to express his or her conflicts, tendencies, and emotions by building an imaginary world. Thus, the present study was conducted with the aim of the effectiveness of sand play therapy therapy on anxiety and achievement motivation of primary students.

Method: This research was a semi-experimental study with a pre-test and post-test control group design. The statistical population included all third grade students of Kerman city in the academic year of 2019-2020. The sample consisted of 50 students from the statistical population who were selected by multi-stage cluster sampling method and randomly assigned to two experimental and control groups (25 students in each group). Hermen's Achievement Motivation Test (1970) and Beck Anxiety Inventory (1990) were used to collect data in this study. In the pre-test phase, both groups were assessed using the mentioned tools, and then sand play therapy was performed in nine 45minute session for experimental group, and the control group did not receive any intervention. The collected data were analyzed by covariance analysis.

Results: The results of data analysis showed that the level of anxiety of the experimental group decreased and the level of motivation, increased $(\mathrm{F}=3 / 865, \mathrm{P}<0 / 01)$ after performing play activities $(\mathrm{F}=8 / 235, \mathrm{P}<0 / 01)$.

Conclusion: Based on the results of this study, it can be concluded that children can express more appropriate and social behaviors through play and use it as a way to evacuate their emotions and reduce their anxious behaviors. Also, sand play therapy allows students who are not motivated and interested in learning lessons to gain new educational and learning opportunities, which in turn increases their motivation to progress.

\footnotetext{
* Corresponding author: Saeideh Khojasteh, Assistant Professor, Department of Educational Science, Faculty of Literature and Humanity Sciences, Payame Noor University, Tehran, Iran.

E-mail addresses: Saeidehkhojasteh333@gmail.com
} 


\title{
اثربخشى شنبازىدرمانى بر اضطراب و انتيزه ويشرفت دانش آموزان مضطرب پايه سوم ابتدايى
}

\author{
سعيده خجسته 1: \\ 1. استاديار گروه علوم تربيتى، دانشكده علومتربيتى، دانشكاه يِيام نور، تهران، ايران
}

\begin{tabular}{|c|c|}
\hline جكيده & 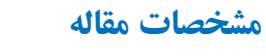 \\
\hline زمينه و هدف: شنبازىدرمانى روشى است غير كلامى، نمادين، و بر اساس تجربههاى خلاق افراد كه در آن دانش آموز با ساختن دنياى & كليدوازهها: \\
\hline خيالى خود در شنها، تعارض ها، تمايل ها، و هيجانهاى خود را بيان مى كند. بدين ترتيب بزوهش حاضر با هدف اثربخشى شنبازىدرمانى & 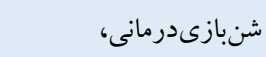 \\
\hline بر اضطر اب و انكيزه بيشرفت دانش آموزان بايايه سوم ابتدايى انجام شد. & اضطراب، \\
\hline روش: اين مطالعه از نظر هدف كاربردى و از نظر روش نيمه تجربى با طرح بيش آزمون و پِ آزمون با دو گروه آزمايش و گواه بود. جامعه & انخيزه بيشرفت \\
\hline آمارى، شامل تمامى دانش آموزان بِايه سوم ابتدايى شهر كرمان در سال تحصيلى 9\-9 بود. نمونه مورد مطالعه شامل •ه دانش آموز از & \\
\hline جامعه آمارى مذكور بود كه به روش نمونه گيرى خوشهاى حندمرحلهاى انتخاب شده و به تصادف در دو گروه آزمايش و گگواه (ها & \\
\hline دانش آموز در هر كروه) جايدهى شدند. براى جمع آورى دادهها در اين مطالعه از دو مقياس اضطراب بكك ( •199) و انكيزه هيشرفت هرمنس & \\
\hline (19V.) استفاده شد. در مرحله بيش آزمون، هر دو گروه با استفاده از ابزارهاى ذكر شده مورد ارزيابى قرار گرفتند و سبس برنامه & \\
\hline شنبازى درمانى به مدت سه هفته، طى q جلسه ه\& دقيقهاى براى گروه آزمايش اجرا شد و گروه گ واه مداخلهاى دريافت نكردند. داده هاى & \\
\hline جمع آورى شده با تحليل كوواريانس توسط نرم افزار SPSS23 تجزيه و تحليل شدند. & \\
\hline 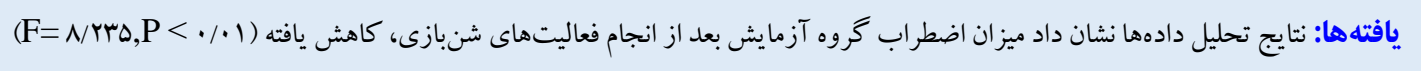 & \\
\hline 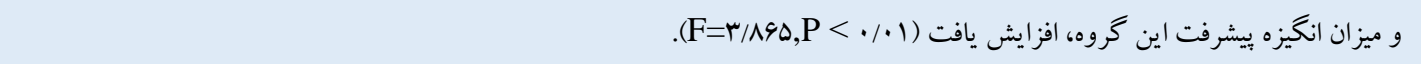 & \\
\hline نتيجه كيرى: بر اساس نتايج به دست آمده در اين مطالعه مىتوان نتيجه گرفت كه كود كان از طريق شنبازى مى توانند رفتارهاى مناسبتر & \\
\hline و اجتماعى ترى را ابراز كنند و از آن به عنوان معبرى براى تخليه احساسات و كاهش رفتارهاى مضطرب خود، استفاده كند. همجنين & 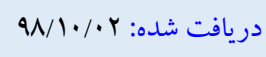 \\
\hline شنبازى درمانى باعث مىشود دانش آموزانى كه انخيزه و علاقهاى نسبت به ياد گيرى دروس ندارند، فرصتهاى آموزشى و يادكيرى جديدى & 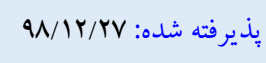 \\
\hline رابه دست آورند كه همين موضوع موجب افزايش انكيزه هيشرفت در آنها مىشود. & 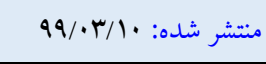 \\
\hline
\end{tabular}


اجتماعى را به انحر اف مى كثـاند (م). البته بايد يادآور شد كه اضطراب ياســى تكاملى و انطباقى اسـت كه همه ما براى هوشسيار بودن و داشـن

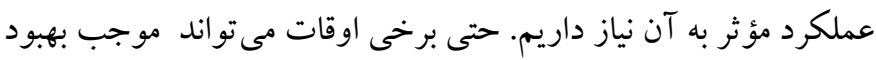

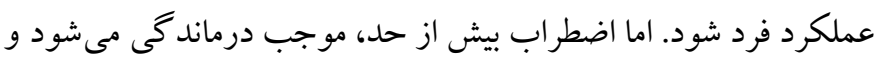
امور مدرسـه، شــل، روابط با دوسـتان، و خانو اده را مختل مى كند (9). كود كـان بـا اختلـالهـاى اضــر ابى به طور معنادارى رويدادهاى منفى بيشترى را در طول زندگى نسبت به كود كان غير مضطرب تجربه مى كنند

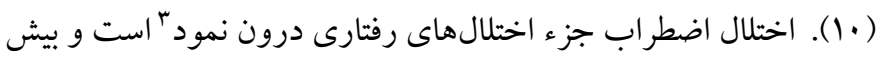

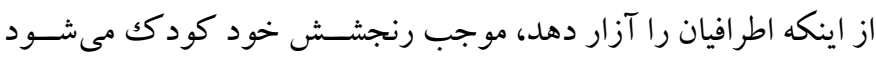
(11). هميجنين به طور كلى سـاير اختلالهاى روانشـناختى به خصـوص

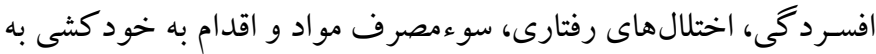

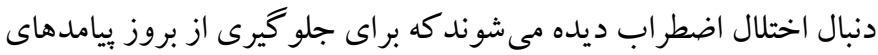

ناكوار بايد سريع تشخيص داده شود و مداخله آغاز گردد (Y (I).

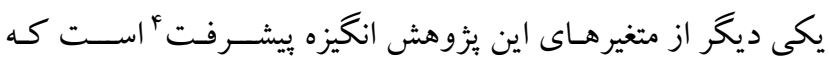
افزايش آن مى تواند آينده شـلى دانش آموزان را متحول سازد. منظور از از

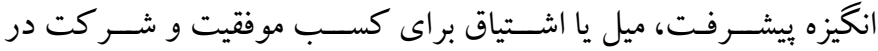

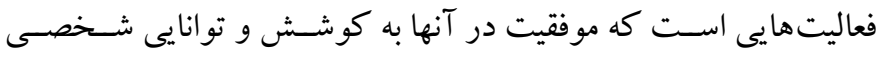

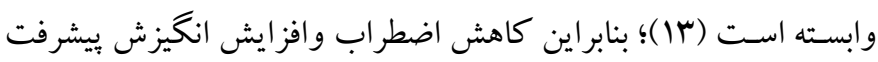

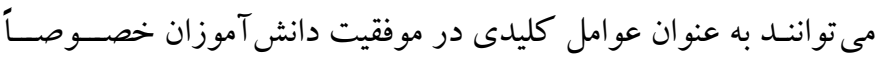
دانش آموزان دوره ابتدايى، سهم تعيين كنندهاى داشته باشند.

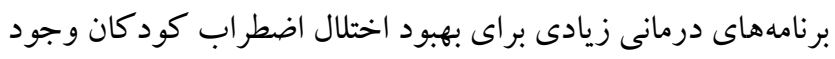

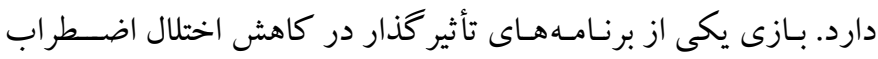

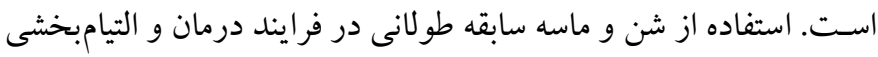

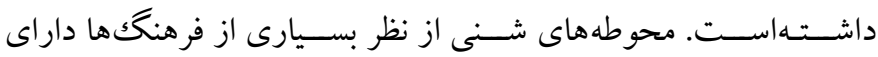

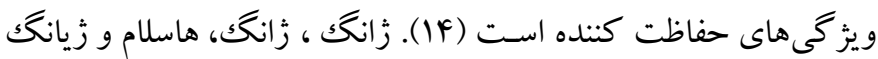
معتقدند كه بازى با اشـكال و عروســك ها در شــنبازىدرمانى كمكك

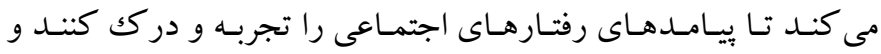

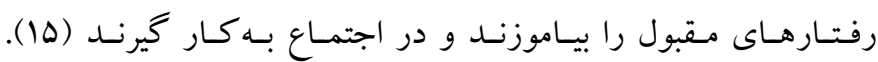

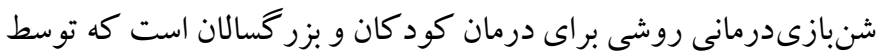

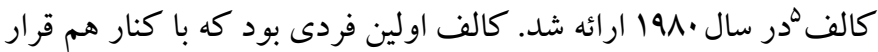

4. Achievement motivation

5. Kallf مقلdo

دوران كودكى يكى از مهم ترين مراحـل زنـدكى اســت كـه در آن

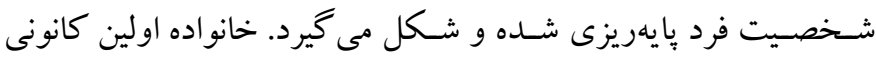

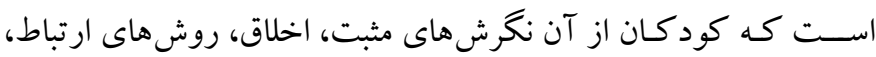
مهارت هاى حل مسـئله، و عملكرد بهينه تحصـيلى را فرا مى گيرند (1). يزووهشها در مورد اختلالات رفتارى كودكان نشــان مىدهدكه بيشـتر

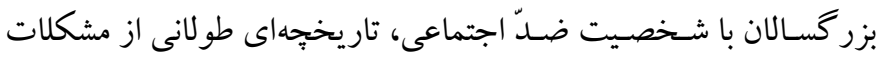

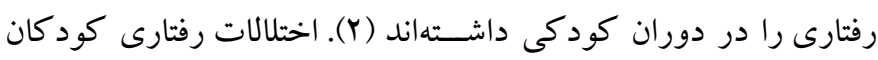

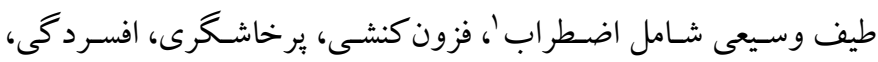

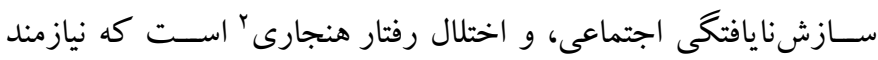
تشخيص و مداخله زودهنگًام هستند (r). اضـطر اب، يكى از رايجترين اختلالهاى روانى كود كان و نوجوانان

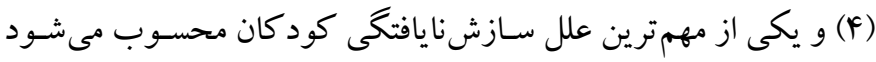

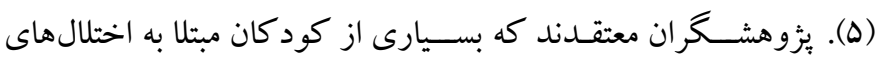
اضـطر ابى و كســانى كه نشـانههاى اضـطراب را در حد خفيف تجربه

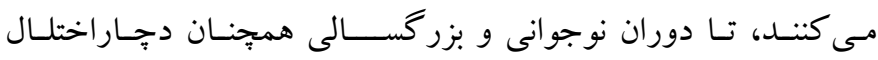

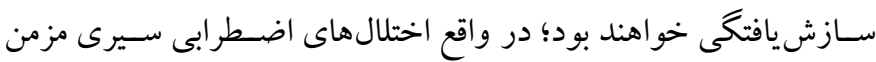

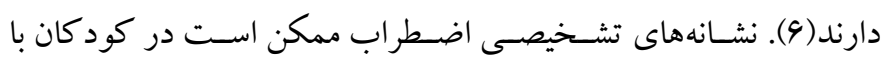
علامتهاى هيجانى و رفتارى بروز كند؛ بنابر اين اين نشانها بايد شناسايى شوند تا در صورت بروز آنها، تشخيص به موقع و اقدام فورى انجام شود.

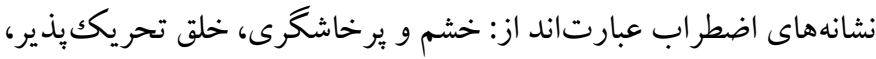

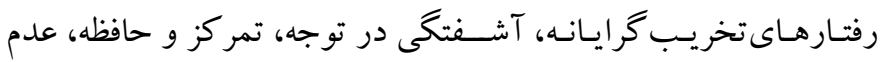
توانيى در مهار فعاليتهاى حركتى، و اختلال در ارتباط (ماند رفتارهاى

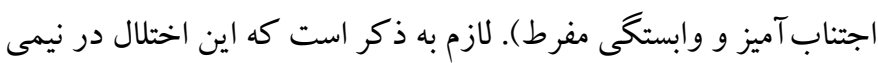

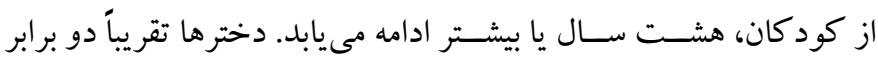

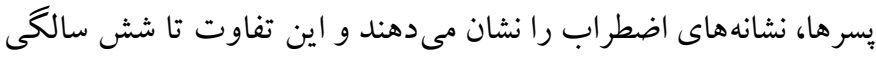

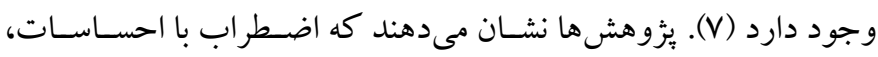

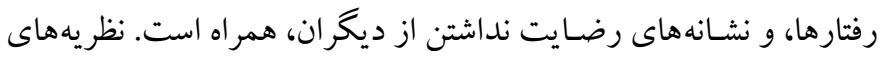

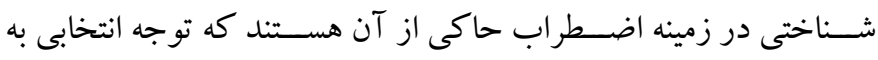
تهلديدها، اضـطراب راشــــــر كرده و قضــاوت در زمينه رويدادهاى

1. Anxiety

2. Conduct Disorder

3. Internalizing 
ترس از فضـاى باز، اضـطراب جدايى، ترس از آســيب فيزيكى، ترس

اجتماعى، وسو اس بى اختيارى، و همجِنين اضطر اب عمومى مىشود.

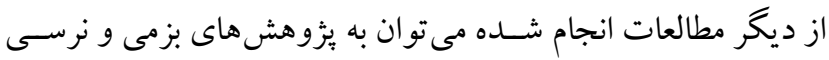

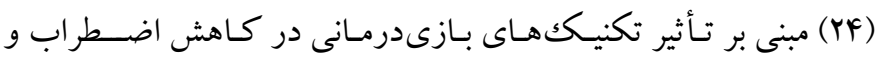
افز ايش سـطح سـازش يافنكى و احسـاسـات مثبت در كود كان؛ مينگك و

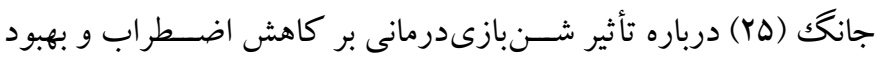

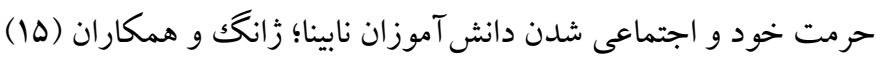

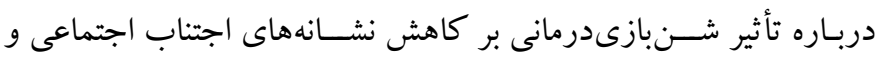

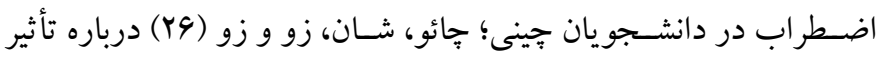
مثبت شـنبازىدرمانى موجب بر مهارتهاى ارتباطى بينفردى؛ گاس و و و

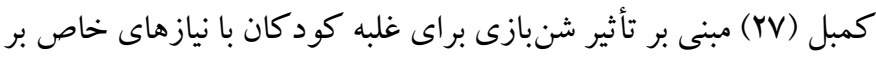
مشـكلات شـناختى، اجتماعى، و عاطفى اسـت؛ كواكى، اهان و ليم (YN)

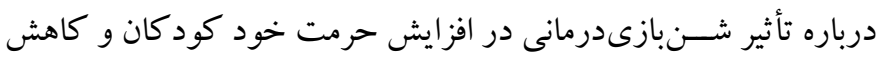

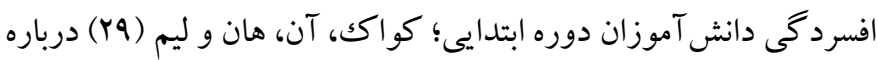

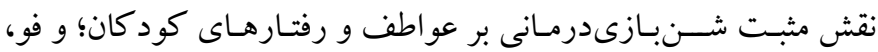

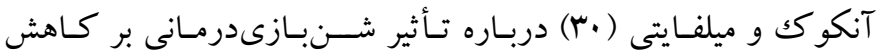

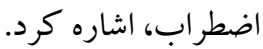

آكيموتو معتقد اسـت كه شـنبازىدرمانى مى تواند وسـيله ارتباطى منــاسـبى براى دوبـاره ســـاختن صـــــهــاى از دســـت رفتـه و

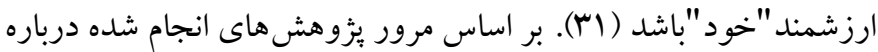

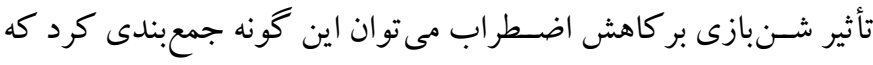

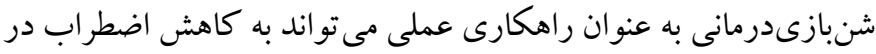

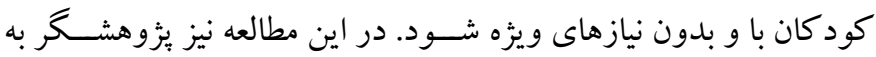
دنبال بررسى تأثير شـنبازىدرمانى بر كاهش اضطر اب و افز ايش انخيزه ييشــفت در دانش آموزان ابتدايى اسـتـ. از مطالعات انجام شـــه درباره نقش بـازىدرمانى بر انكيزه ويشــــفت مى توان به مواردى مانند يُزوهش

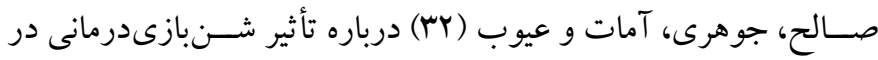

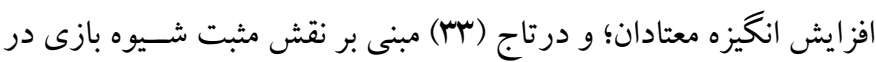
مقايسه با روش سـتى در بهبود انكيزه بيشـرفت تحصسيلى دانش آموزان،

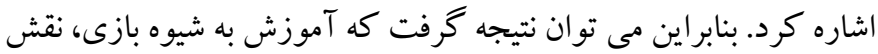

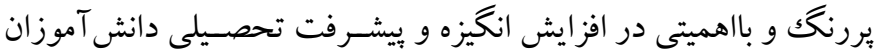

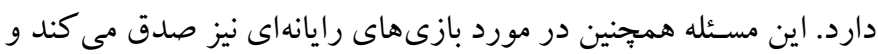

دادن مجسـمه هاى كوجگك و شسنى و به كار گيرى اصـول نظريه يونگك، مر اجعـان خود را درمـان كرد. يونگك معتقد بود يكك تجربه هيجانى كه با

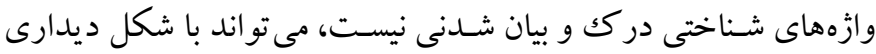

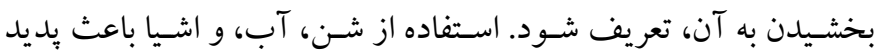
آمدن وضعيتى فوقالعاده مىشود و آنجه از ناخود آكاه شخص درمانجو مى گذرد، به دسـتان سـازندهاش منتقل مىشـود. شـنبازىدرمانى كالف، روشسى اسـت غير كلامى، نمادين، و مبتنى بر تجربههاى خلاق، كه در آن

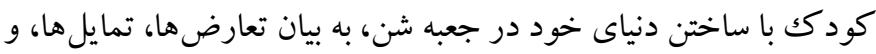
هيجانهايش مى يردازد (19). روش شــنبازىدرمانى نوعى بازىدرمانى

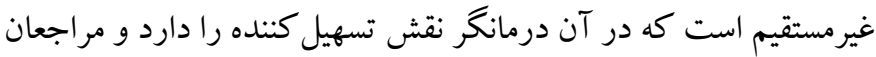
مى تو انند هيجانات و تصــويرهاى ذهنى خود را آزادانه و با اســفاده از

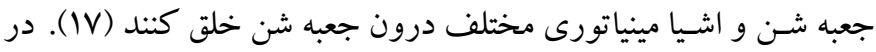

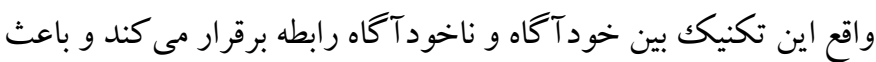

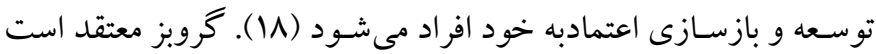
كه شنبازىدرمانى روشىاست كه به طور اعم در درمان كود كان به كار

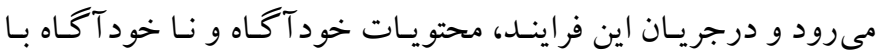

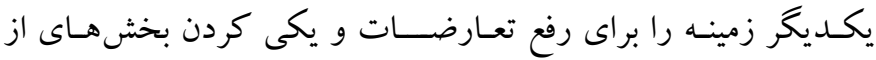

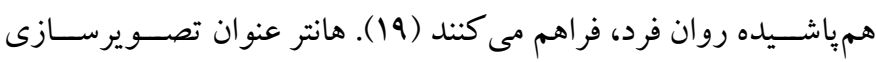

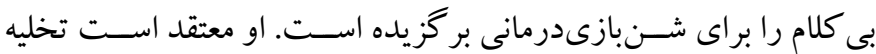
هيجانى كود كان از طريق شـنبازىدرمانى قدرت يافته و تقويت مى شود

درباره تأثير بازىدرمانى با شـيوههاى مختلف، مطالعات مختلفى در

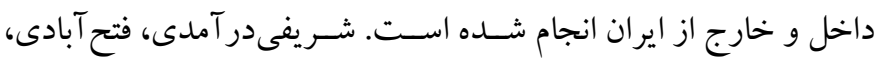

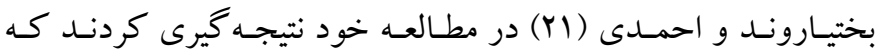
بـازىدرمـانى با اسـتفاده از شــن، موجب كاهش رفتارهاى جالشـى و اضطر اب كود كان مبتلا به اختلال اوتيسم با كاركرد بالا شد. شمسىيور و

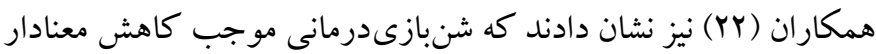

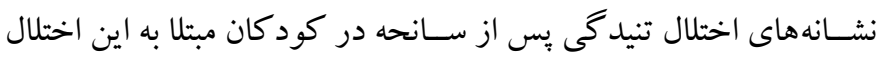

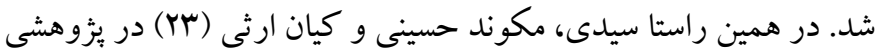

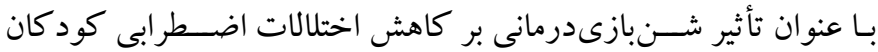

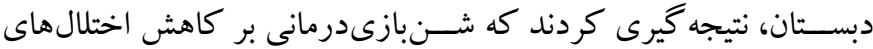
اضـطر ابى تأثير معنـادارى دارد و همجنين باعث كاهش على عليم هر اس و و 
شنبازىدرمانى انتخاب، و به صورت تصادفى در گروههاى آزمايش

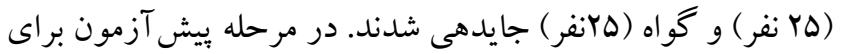

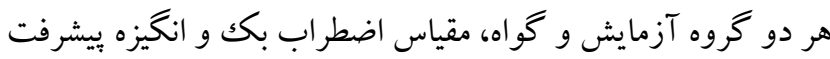
هرمنس توسط دانش آموزان تكميل شد، سبس برنامه شنبازى دودرمانى به مدت سـه هفته ، طى qجلسـه ذأ دقيقهاى (هر هفته سه جلسه) براى

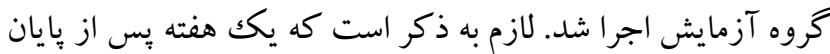

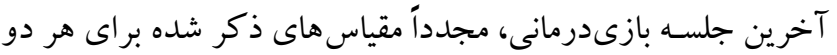

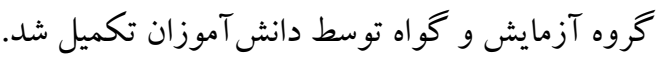
ب) ابزار

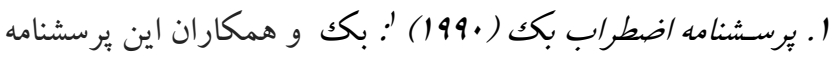

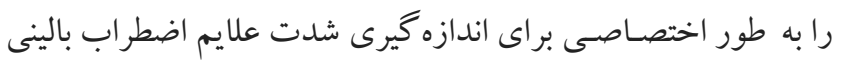
در افراد تدوين كردند. يرسـشــنامه اضـطراب بكك، يكك مقياس كويهاى است كه آزمودنى در هر گويه يكى از جهار گزينهاى را كه نشـان دهنده شــت اضـطر اب فرد اســت را انتخاب مى كند. از اين

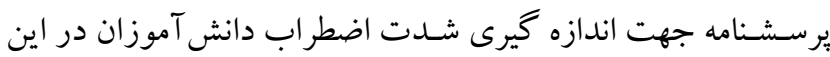

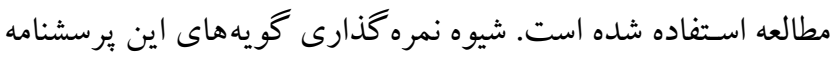

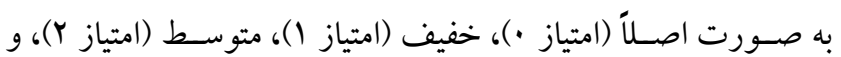

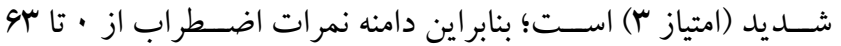
خواهد بود. در صورتى كه نمره به دست آمده، در دامنه · تا V باشد،

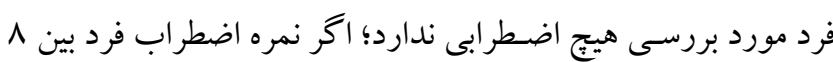

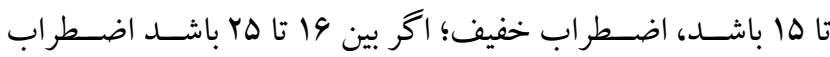

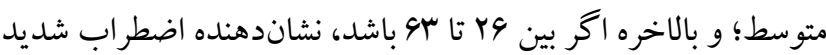
است. للازم به ذكر است كه اين برسشنامه مؤلفه ندارد و فقط نمره كل ارائه مىدهد (ها). اين برسـشــامه از اعتبار و روايى باليى برخوردار است. ضريب همسانى درونى آن با استفاده از ضريب آلفاى كرونباخ

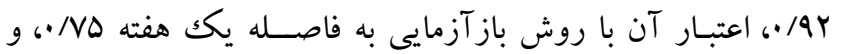

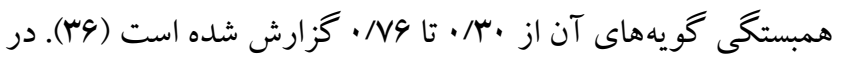
مطالعه رفيعى و ســيفى اعتبار اين يرسـشــنامه با اســفاده از آلفاى

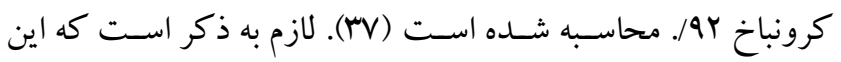
يرسشنامه، نـهـ تنهـا در كــار ارزيـابى و تشخيص كمككرسان است،
مطالعات نشــان مىدهند كه روش تدريس مبتنى بر بازىهاى رايانهاى بر انخيزه بيشـفت تأثير مثبت دارد (Fץ). بررسى بيشينه مطالعات انجام شده

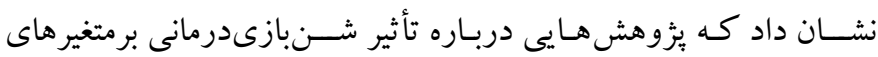
مختلف از جمله اضـطراب انجام شــده اســت، اما تاكنون يزؤوهشى با

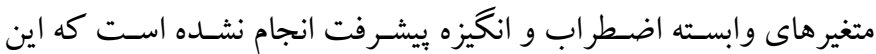
موضسوع جنبه نو آورى اين مطالعه را نشــان مى دهد. بدين ترتيب هدف

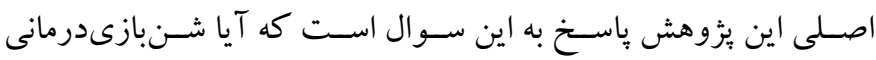

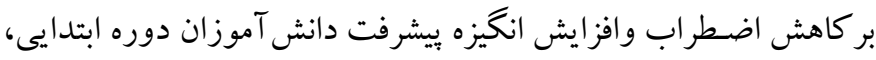

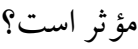

روش الف) طرح يزوهش و شـركت كنند كان: اين مطالعه از نظر هدف كاربردى و از نظر روش نيمه تجربى با طرح ييش آزمون و يس آزمون

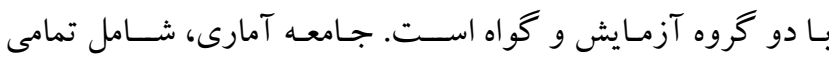
دانش آموزان دختر يايه سـوم ناحيه ا شـهر كرمان در سـال تحصسيلى رونى

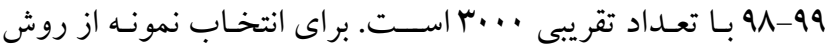
نمونه گيرى خوشـهاى جندمر حلهاى استفاده شد. بدين صورت كه در

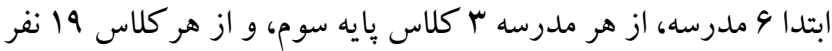
به طور تصـادفى انتخاب شدند. دامنه سنى افراد نمونه بين ^ تا 9 سال

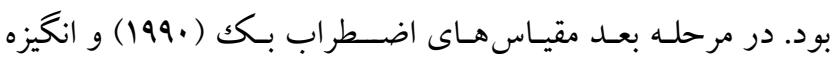
بيشـرفت هرمنس ( •l9V) به آزمودنى ها جهت تكميل داده شـــ. بـ

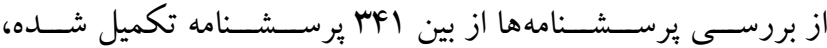
.

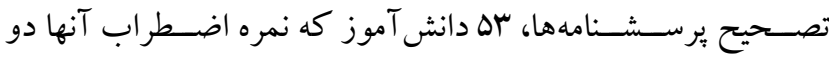

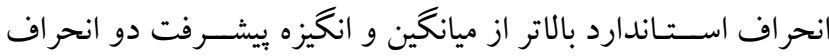
استاندارد پيايين تر از ميانگين بود، انتخاب شدند.

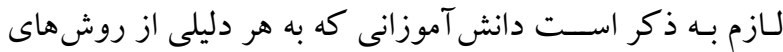
ديخر درمانى شـامل خدمات مشاورهاى يا يزشكى استفاده مى كردند، از نمونه حذف مى شدند؛ بنابراين با توجه به معيارهاى ورود و خروج

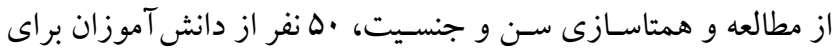
شـركـت در مرحلـه دوم يُزوهش يعنى شــركـت در جلســـات 


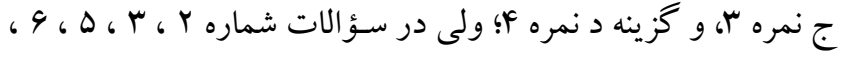

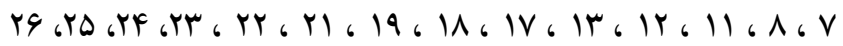

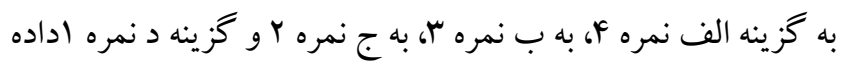

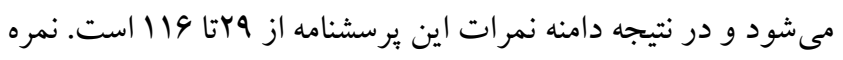

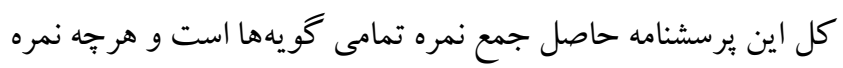

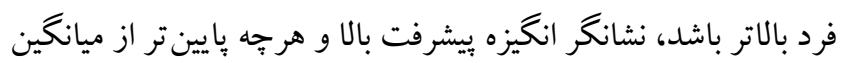
باشد، بيانگر انگيزه بيشرفت بايين در فرد است (هץ).

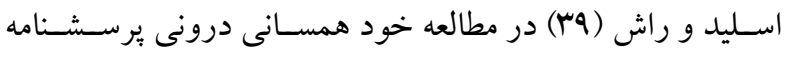

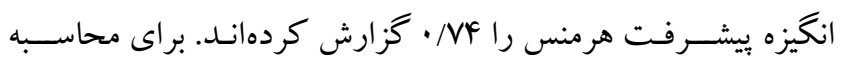

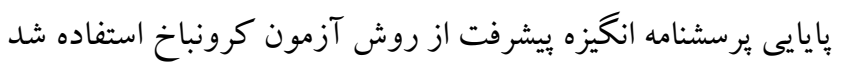

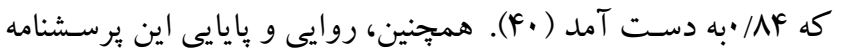
در ئزوهش نوحى و همكاران (FI) نيز به تأييد رسيده است.

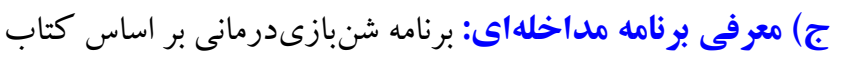

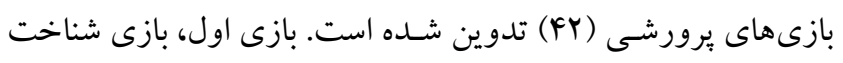
قلعهاى شـنى بوده اسـت. هدف اين بازى تخليه انرزى هاى منفى و

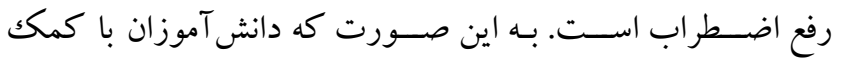

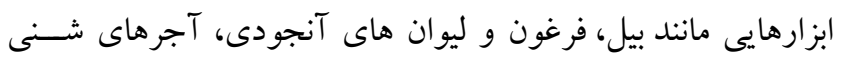

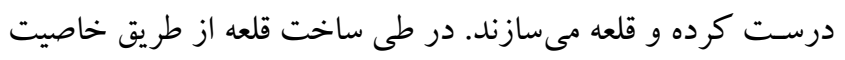
تويولوزيكك شــنهـا، پس از فروريختن با خيال راحت قلعه هارا

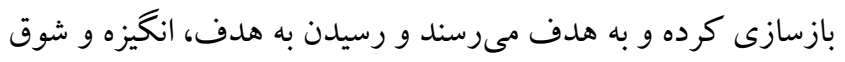
آنهارا بالا مىبرد و باعث تخليه انرزى هاى منفى و رفع اضطراب آنان

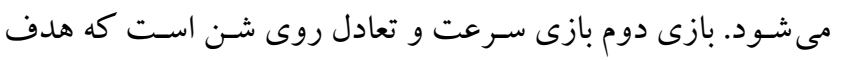

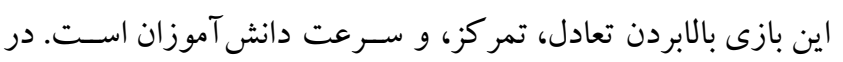

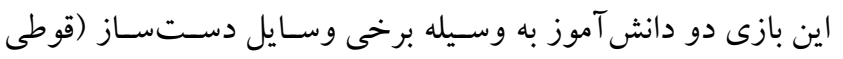

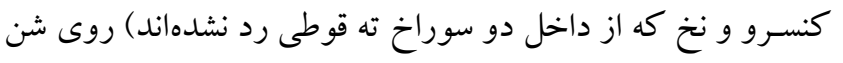
ها مسـافتى را مسـابقه مىدهند. در حين اين بازى كه با شـادى همر اه

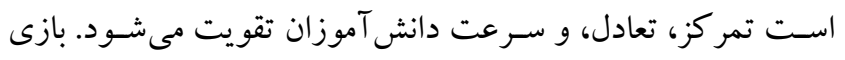

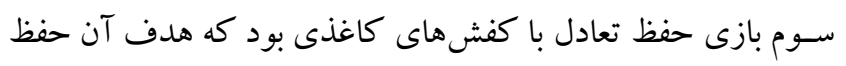
تعادل و تمر كز روى شـنها بود. بازى جهارم، بازى نوشتن محاسبات رياضى(جمع، تفريق، ضرب، و تقسيم) روى شنها بود. هدف اين بـازى رفع اضــطراب در محاســبات رياضـى و تقويت انخيزه در
كه مى تواند در ارزيابى هاى درمانى و ســنجش اثربخشـى درمان نيز

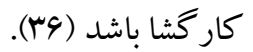

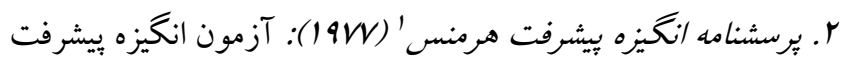
هرمنس توسط هربرت هرمنس سـاخته شده كه شامل وب گويه است

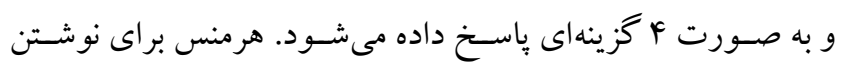

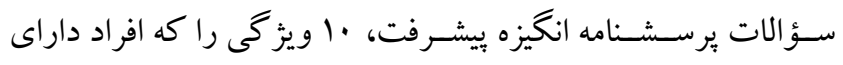

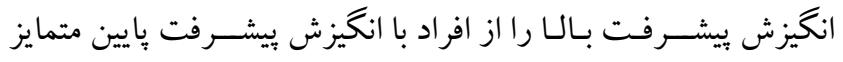

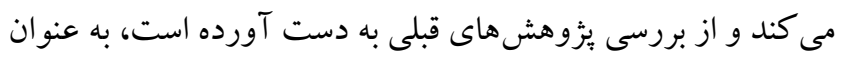

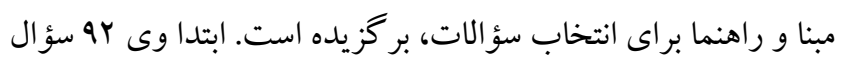
را براى برسـشــنامه تهيه كرد و در نهايت بر اسـاس ميزان ضـريب

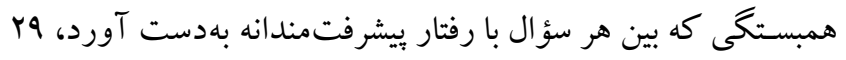

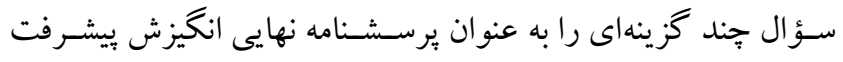
انتخاب كرد. ده ويز گى كه افراد داراى نياز به بيشرفت بالا را از افراد

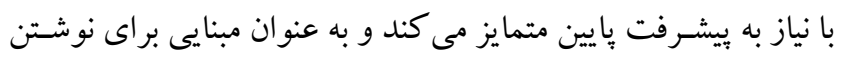

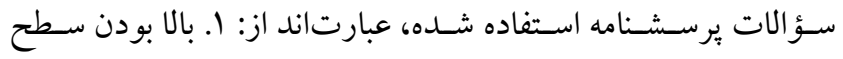

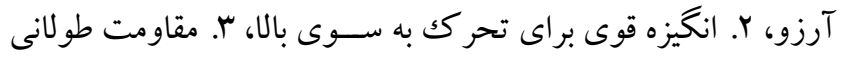
در مو اجهه با تكاليف با سـطح دشـوارى متوسـط، ث. تمايل به اعمال

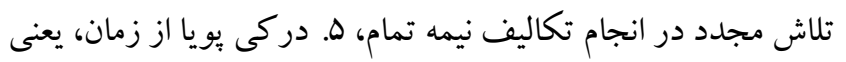

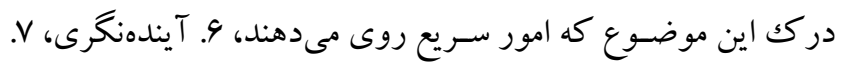

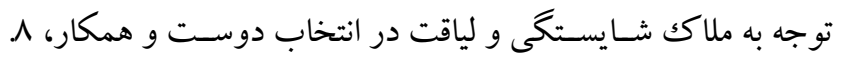
بازشـناسـى از طريق عملكرد مطلوب در كار، 9. انجام كار به بهترين

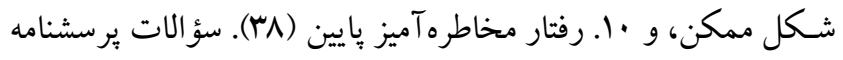
به صـورت جملات ناتمام بيان شـده اسـت و به دنبال هر جمله، جند كزينه داده شـده است. جهت يكسـانسازى ارزش سؤ الات براى هر هر

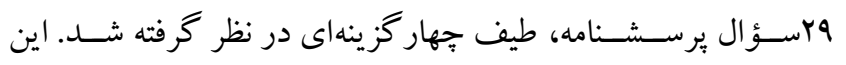

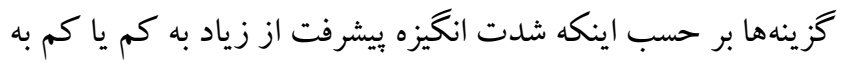

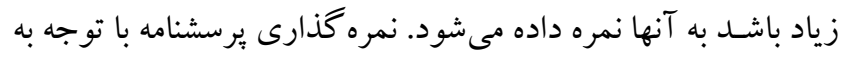

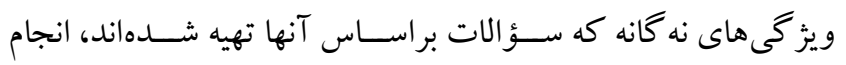

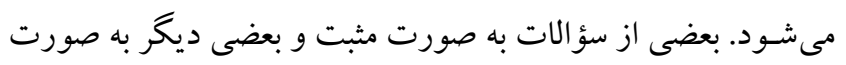

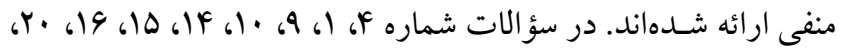
rr 
سبدى مى گذارد كه روى هر كدام تعدادى عبارت ضرب نوشته شده

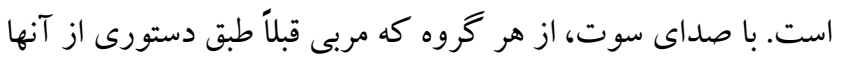

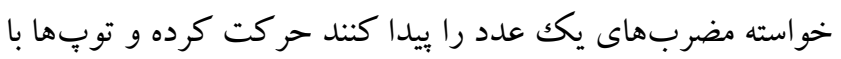

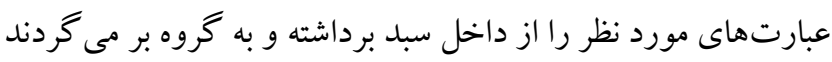

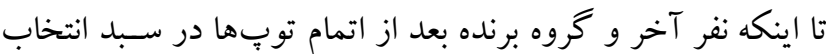

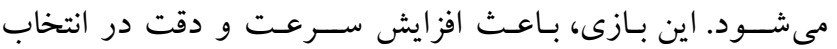
عبارتهاى ضـرب دانش آموز مى شـود. للازم به ذكر اسـت كه افر اد اد

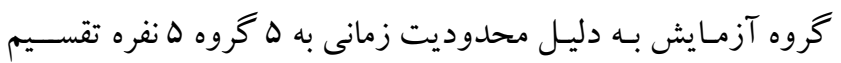
شدند و به نوبت وارد استخر شن مى شدند و به بازى مى يرداختند. نام

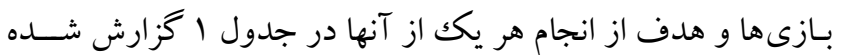

دانـش آمـوزان بوده اســـت. طى اين بــازى معلم از دانش آموزان

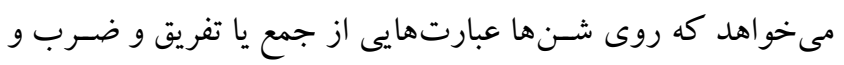

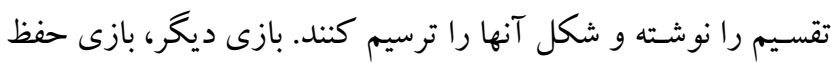
تعادل روى شنها بوده است كه هدف آن حفظ تعادل و تمر كز بوده

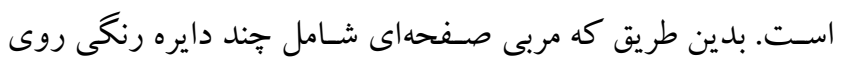
شـنها يهن مى كند و Y الى ع نفر از دانش آموزان را انتخاب و كنار

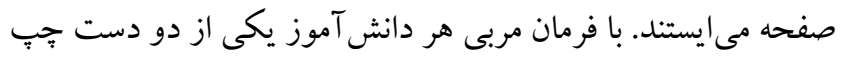

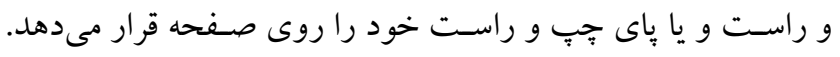

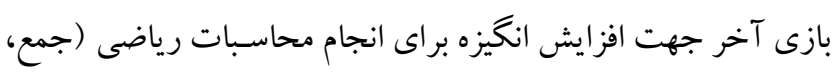
تفريق، ضرب، و تقسيم) بوده است. در اين بازى دو گروه دانش آموز

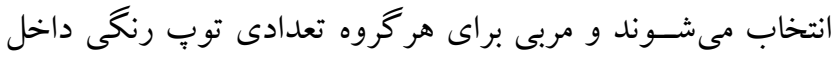

جدول ا: جهارجوب كلى برنامه شنبازىدرمانى

\begin{tabular}{|c|c|}
\hline هدف از انجام بازى & نام بازى \\
\hline تخليه انرزىهاى منفى و رفع اضطراب & بازى شناخت قلعههاى شنى \\
\hline بالابردن تمر كز و سرعت دانش آموز & 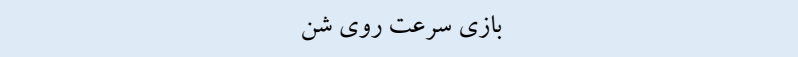 \\
\hline ت تعادل و تمركز & بازى حفظ تعادل با كفشهاى كاغذى \\
\hline رفع اضطراب در محاسبات رياضى و تقويت انخيزه در دانش آموزان & بازى نوشتن محاسبات رياضى(جمع، تفريق، ضرب و تقسيم)روى شن \\
\hline حفظ تعادل و تمركز & بازى حفظ تعادل در روى شنها \\
\hline افزايش سرعت ، دقت و رغبت جهت انجام محاسبات رياضى(جمع، تفريق، ضرب و تقسيم) & بازى جهت افزايش انخيزه براى انجام محاسبات رياضى (جمع، تفريق، ضرب و تقسيم) \\
\hline
\end{tabular}

تكميل كنند. همجينين در هر جلســه مداخله نيز تمام تمرينات بســته آموزشس با دقت و نظارت كامل انجام مىشـــ و دانش آموزان گرُوه

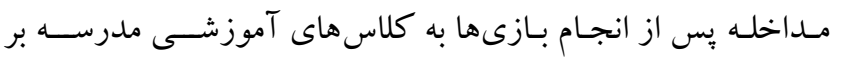

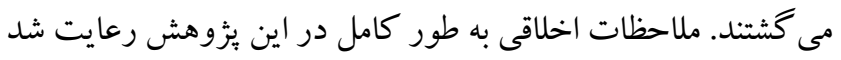
و مجوز اجراى يثزوهش در مدرســه از حراسـت آموزش و برورش كسـب شــــ. همجنين رضـايت دانش آموزان و والدين آنها جهت شر كت در مطالعه، جلب شد. همجنين به دانش آموزان و والدين آنها

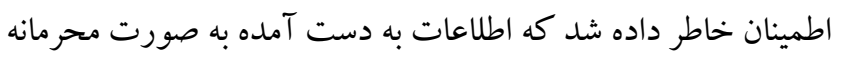
حفظ خواهنــ شــــ و به لحاظ رعايت اخلاق، بس از اتمام يزوهش، جلسات بازى درمانى به صورت خلاصه براى گروه گواه نيز اجرا شد. لـازم بـه ذكر اسـت كـه تجزيـه و تحليـل دادههـا به كمكك نرمافزار

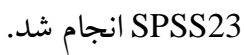

د) روش اجرا: بعـد از كســب مجوز از اداره آموزش و يرورش شـهرستان كرمان و تأييد يرسشنامه ها توسط حراست و هسته مشاوره،

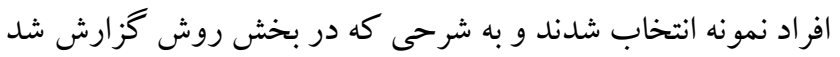

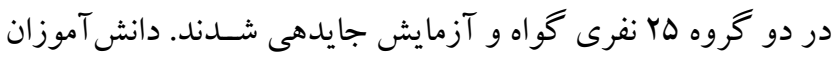

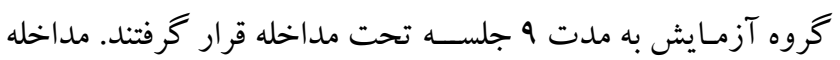

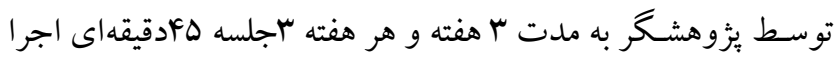

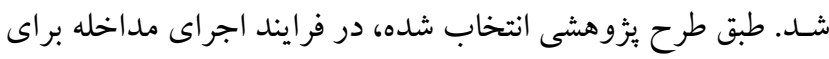

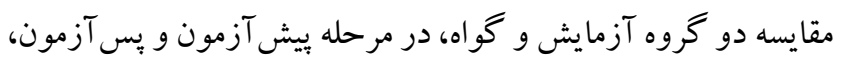
يرسـشـنامه هاى اضطر اب بكك و ييشـرفت تحصسيلى هرمنس توسط ونس

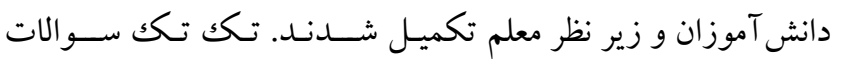

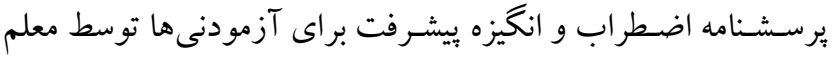
خو انده شد و هر جا وازهاى گنگك و نامفهوم بود برايشان توضيح داده

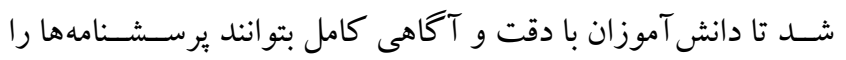


بودن توزيع متغيرها در گروهها گزارش شده است. با توجه به اين جدول

يافته ها

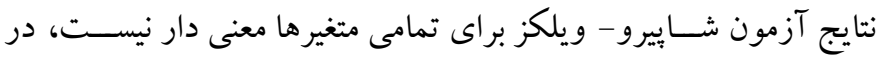
ميـانخين و انحر اف اســتاندارد نمرات بيش آزمون-ِّ آزمون متغيرهاى

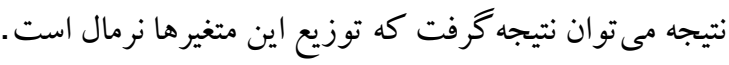

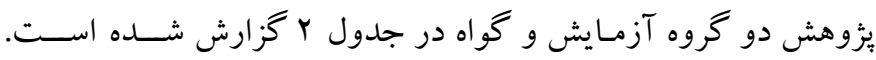

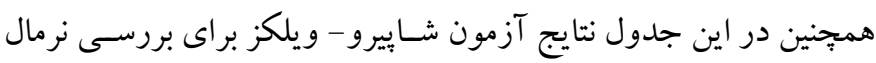

جدول r: شاخص هاى توصيفى نمرات بيش آزمون- بـ آزمون در دو كروه آزمايش و كواه

\begin{tabular}{|c|c|c|c|c|c|c|}
\hline $\mathbf{P}$ & شايِيرو ويلكز & انحراف استاندارد & ميانگين & كروه & وضعيت & متغير \\
\hline$\cdot / T Y V$ &.$/ 99 V$ & $\cdot / T M V$ & $r / \mu F$ & آزمايش & \multirow{2}{*}{ ييش آزمون } & \multirow{4}{*}{ اضطراب } \\
\hline$\cdot / r \cdot q$ & . /QTY & - / YFq & r/rr & كواه & & \\
\hline$\cdot / M A Y$ &.$/ 9 Y 4$ & $\cdot|| F \mid$ & $r / l l$ & آزمايش & \multirow{2}{*}{ يس آزمون } & \\
\hline . MAY &.$/ 949$ & . /rIF & r & كواه & & \\
\hline$\cdot / 109$ &.$/ 199$ & $1 . \Delta v$ & $r / . r$ & آزمايش & \multirow{2}{*}{ بيش آزمون } & \multirow{4}{*}{ انخيزه يِشرفت } \\
\hline$\cdot /$ TAF & $\cdot / 991$ &.$/ \cdot F Y$ & $r / 99$ & كواه & & \\
\hline . / & . /90r & $1 \cdot \mathrm{Av}$ & r/vA & آزمايش & \multirow{2}{*}{ يس آزمون } & \\
\hline.$/ 119$ & - /QFF &.$/ .01$ & r/VG & كواه & & \\
\hline
\end{tabular}

وابسته در گروهها نشان داد كه واريانس اضطراب در گروه ها برابر است

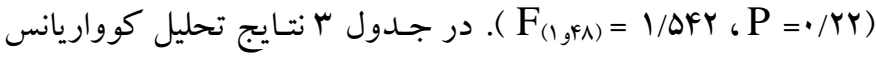

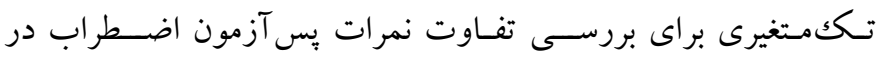

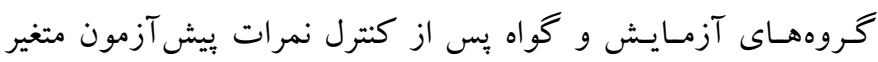
اضطراب ززارش شده است.
براى بررسى اثربخشى شنبازىدرمانى براضطر اب دانش آموزان، از

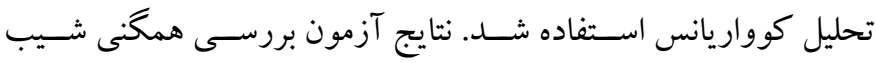
ركرسيون ييش آزمون و يس آزمون اضطراب در گروه آزمايش و گو اه نشـان داد كه شيب رخرسيون در هر دو گروه برابر اسـت (P

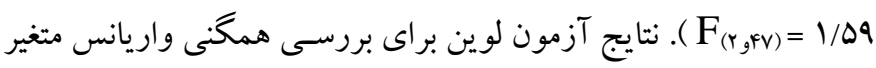

جدول ب: نتايج تحليل كوواريانس تككتغيرى براى بررسى تفاوت كروه آزمايش و كواه در اضطراب

\begin{tabular}{|c|c|c|c|c|c|c|}
\hline اندازه اثر & $\mathbf{p}$ & F Tماره & ميانكين مجذورات & درجه آزادى & مجموع مجذورات & منبع تغييرات \\
\hline . /Var &.$/ \cdot 1$ & $r \cdot / \Delta r r$ & FrI/911 & 1 & Frl/g11 & ييش آزمون \\
\hline \multirow[t]{2}{*}{. Ars } & **** $\cdot / \cdot \cdot 1$ & N/TrD & $I V \cdot / \cdot r$ & 1 & $I V \cdot / \cdot r$ & عضويت گروهى \\
\hline & & & 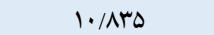 & FV & $0.9 / Y q$ & خطا \\
\hline
\end{tabular}

مى توان كفـت كه شــنبـازىدرمانى موجب كاهش ميزان اضـطراب

$$
\text { دانش آموزان دختردوره ابتدايى مىشود. }
$$

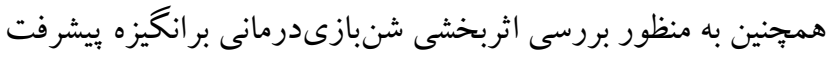

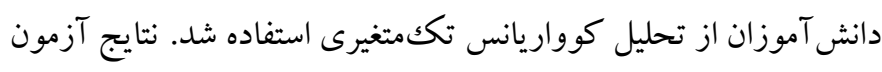

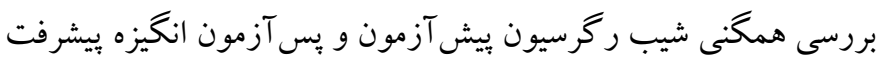

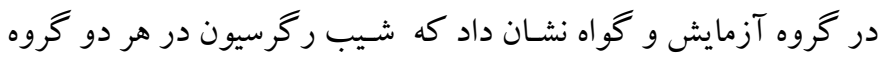

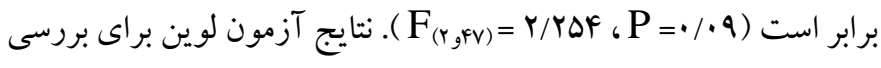

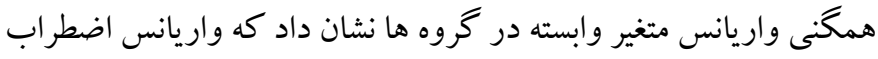

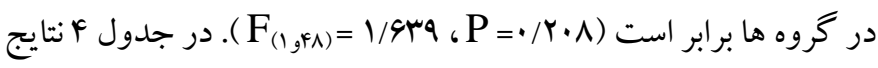

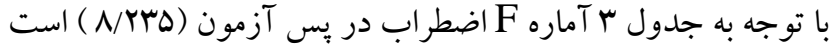

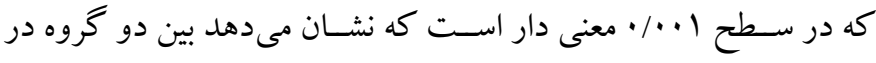

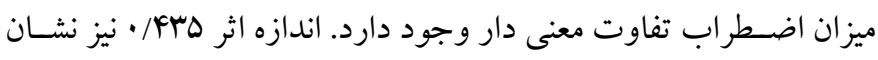

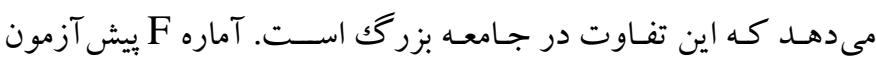

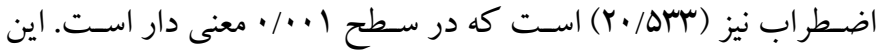
يافته نشــان مىدهد كه بيش آزمون تأثير معنىدارى بر نمرات بـ آزمون

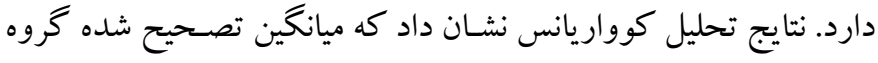

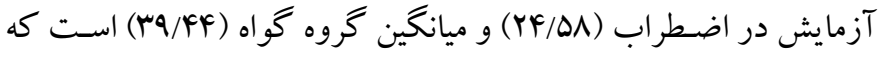

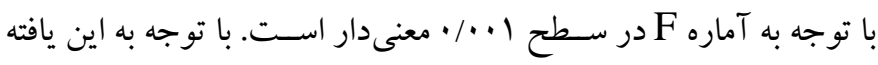


تحليل كوواريانس تككمتغيرى براى بررسـى تفاوت نمرات پِ آزمون

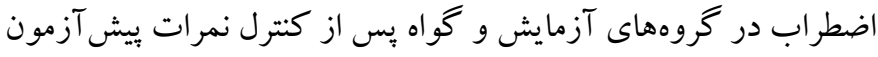

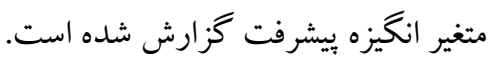

جدول ع: نتايج تحليل كوواريانس تككتغيرى براى بررسى تفاوت كروه آزمايش و كواه در انتيزه بيشرفت

\begin{tabular}{|c|c|c|c|c|c|c|}
\hline اندازه اثر & $\mathbf{p}$ & 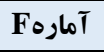 & ميانكين مجذورات & درجه آزادى & مجموع مجذورات & منبع تغييرات \\
\hline.$/ 011$ &.$/ .1$ & $11 / I r V$ & $|F \Delta /| M A$ & 1 & $|F \Delta /|{ }^{\prime} \Lambda$ & ي ييش آزمون \\
\hline \multirow[t]{2}{*}{ - /VDF } & 䄅巻 $=/ . .1$ & r/A9D & $F \mid / \Delta \wedge 1$ & 1 & $F \mid / \Delta \wedge 1$ & عضويت گروهى \\
\hline & & & V/GFD & FV & $r \Delta Q / T r F$ & خطا \\
\hline
\end{tabular}

كـاهش اختلال هاى اضـطر ابى، بهبود ســازش يافتكى اجتماعى، كاهش احساس نامنى روانى، افزايش حرمت خود، كاهش اضطر ابر اجتى اجتماعى و

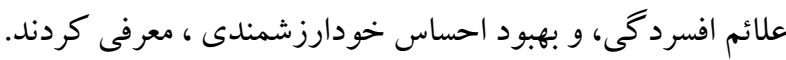

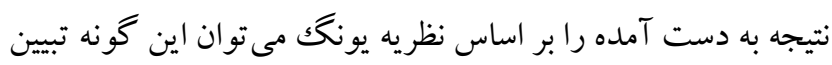

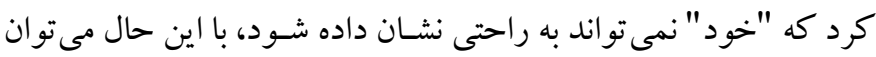

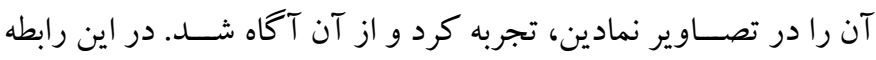
ماهيت نمادين و ديدارى شـرايط شـنبازى باعث تبديل شدن آن به يكك

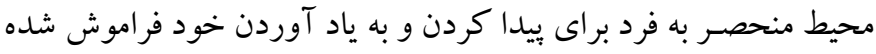

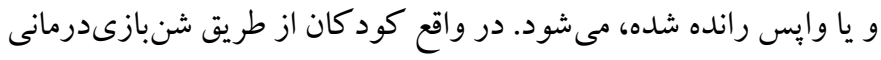

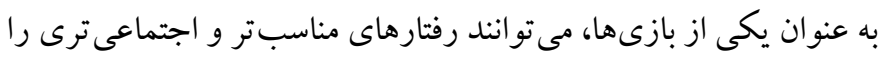

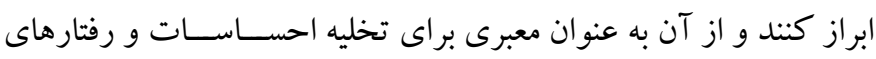

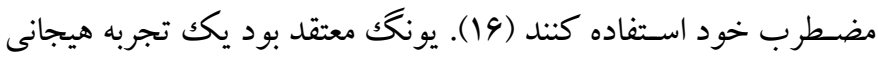
كه با وازههاى شـناختى درك و بيان شـدنى نيست، مى توان به آن شكل

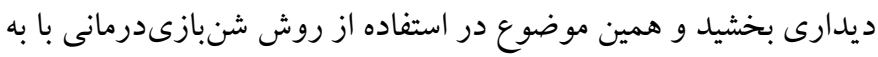

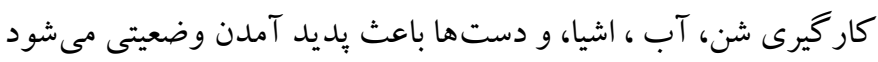

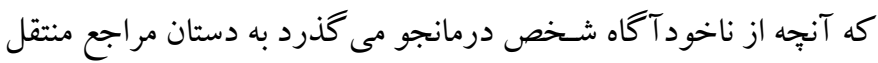

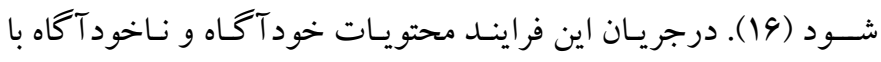

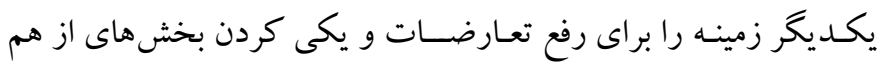

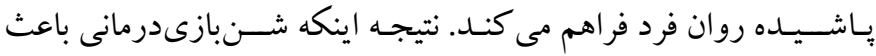
مىشـود كه تخليه هيجانى كود كان از طريق بازى، قدرت يافته و تقويت

شود (19).

دانش آموزان وقتى در شن ها بازى مى كنند، احساس آزادى و رهايى

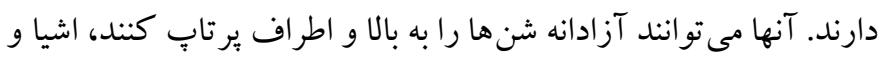

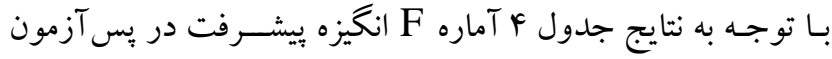

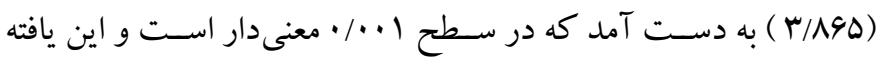

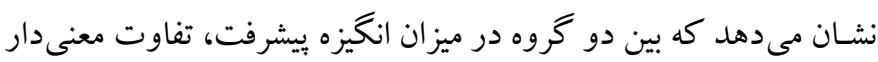

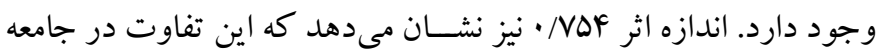

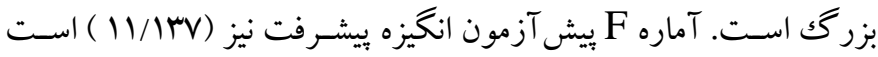

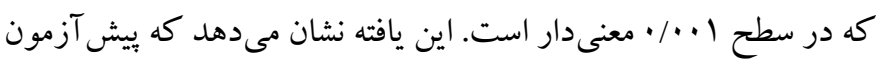
تأثير معنى دارى بر نمرات بس آزمون دارد. نتايج تحليل كوواريانس نشان داد كه ميانخين تصحيح شده گروه آزمايش در انخيزه بيشرفت (AV/999)

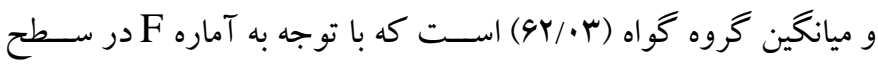

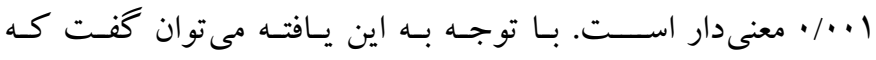

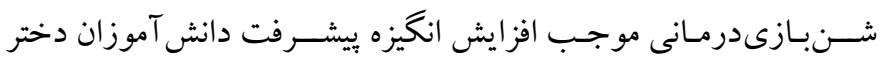

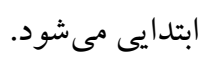

\section{بحث و نتيجه تيرى}

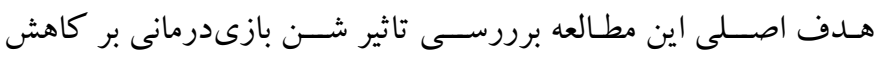

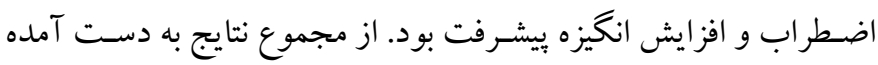

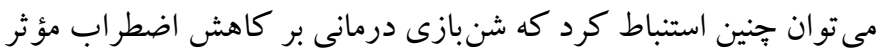

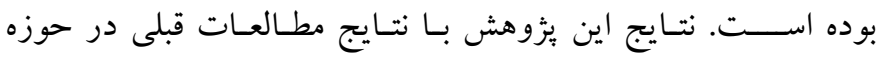
شنبازىدرمانى و اضطراب در مورد كود كان از جمله شريفى در آمدى و

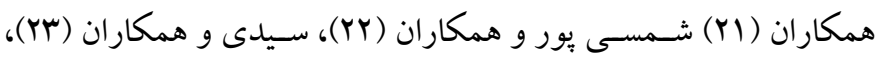

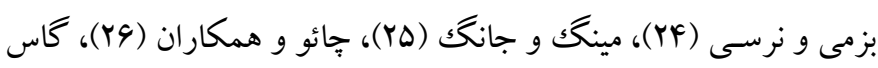

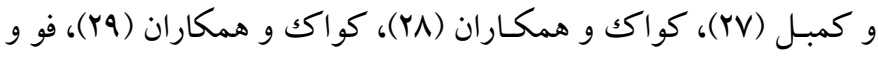

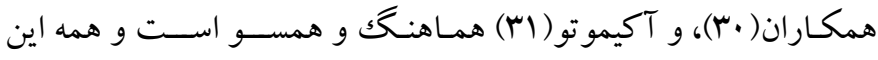

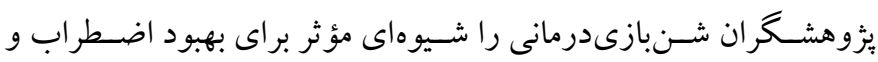


فرايند سـاختن يكك محوطه شـنى براى كود كان جذاب اسـت و بيان

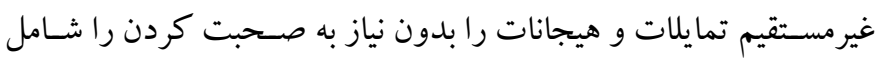

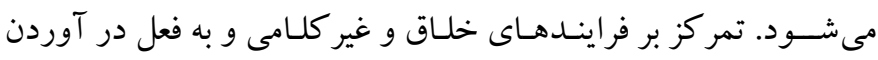

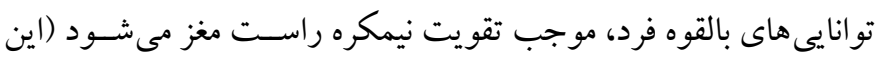

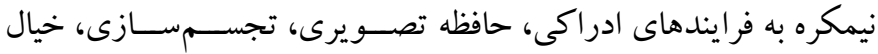
يردازى، تخيل، و احسـاسـات مربوط مىشـود). تخيل در حقيقت، روش كود كك براى غلبه يافتن بر مشكلات محيطى است. كودكك در اين شيوه،

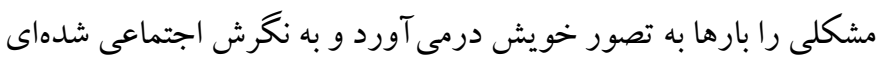
دسترسى مى يابد كه سـرانجام در سطحى از عمل يا رفتار تجلى مى يابد.

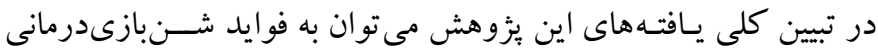

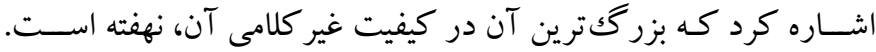

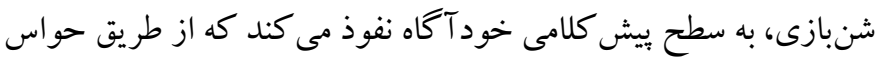

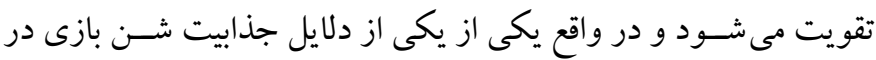

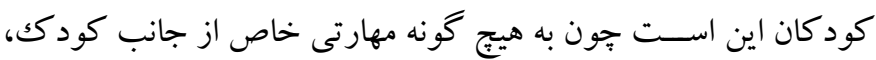

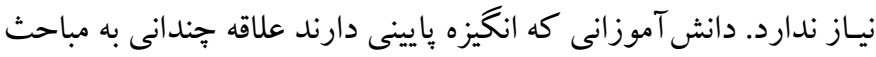

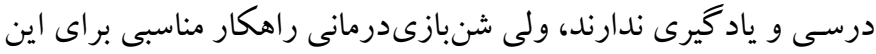
كونه دانش آموزان است؛ بنابر اين زمانهايى كه كود كان در شنه ها به به دور

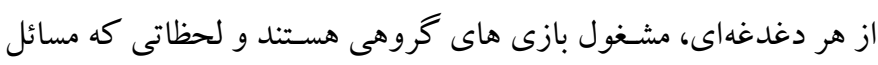

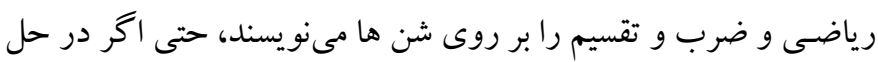

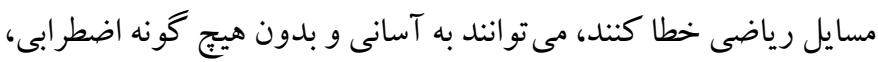

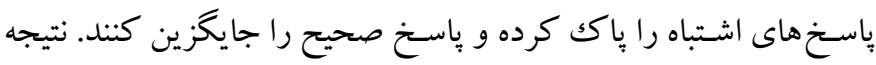

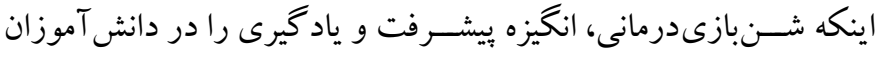
تقويت مى كند.

يكى از محدوديت هاى اين ئزوهش، اســفاده از يرســــــامه براى

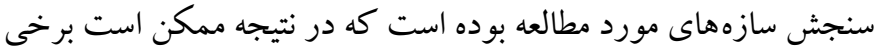

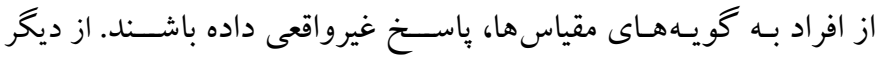

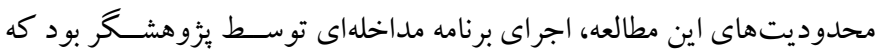

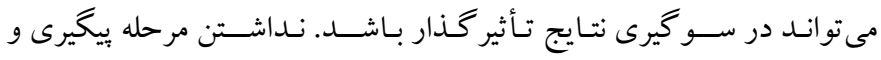
تفـاوتهـاى فردى دانش آموزان در مورد در كك مفـاهيم و كامل كردن مدرن

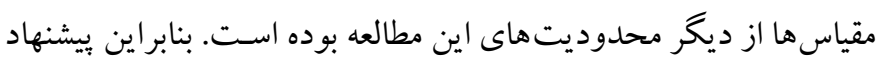
مى شود كه اين مطالعه با رفع محدوديتهاى روش شناختى ذكر شده و با ساب بررسـى سـاير متغيرهاى روانشــناختى انجام شـــود تا بر دقت نتايج و
حتى اسباببازى هايشـان رازير شنها مدفون كنند، با دستانشان تصاوير

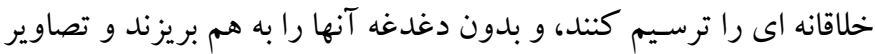
ديخرى بسـازند. همين احساس رهايى و آزادى موجب كاهش اضطراب در دانش آموزان مىشود. در واقع تخليه هيجانات منفى باعث تجربه بيشتر

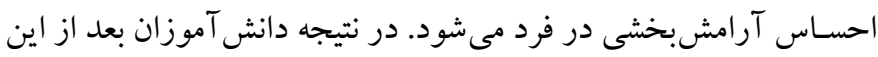

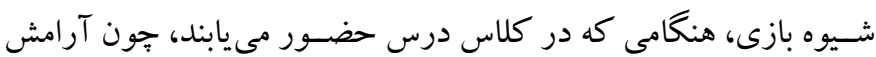

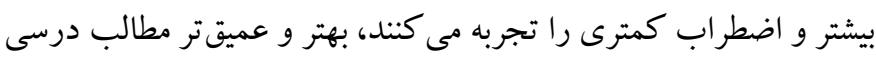
رامى آموزند. شـنبازىدرمانى شـرايطى مهيا مى كند تا دانش آموزان به برونريزى انرزى نهفته خود اقـدام كنــــ. بـازى در شــنها به دانش آموزان قدرت مىدهد و همين قدرت باعث كاهش اضطر اب و انرزى هاى منفى در آنها مىشـود. علاوه بر آن، دانش آموزان از طريق شـــــازى درمانى مى تو انند

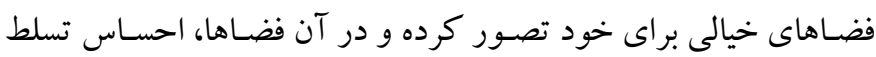

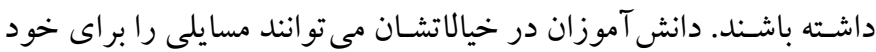
بازسـازى كنند كه در واقعيت امكان واقعيتبخشسى نداشـته و در دنياى واقعى اتفاق نمى افتند. بنابر اين اين كود كان در طى فرايند بازى مى تواند براى مسايل مختلف، راهحل هايى بيدا كنند. نتـايج اين مطالعه همجنين نشــان داد كه شــنـبازىدرمانى بر انخيزه

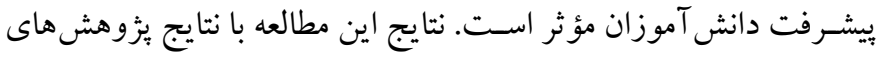

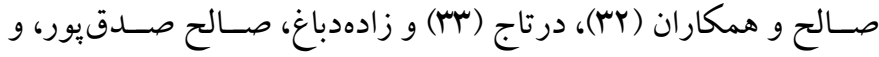
امينى فر (KF) همخوانى دارد. اين يزوهشـــان نيز در مطالعات خود تأثير مثبت شـنبازى درمانى را بر بهبود انخيزه و ييشرفت تحصيلى نشان دادند.

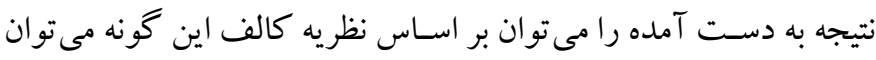
تبيين كرد كه شنبازىدرمانى روشى است غير كلامى و نمادين كه در آن

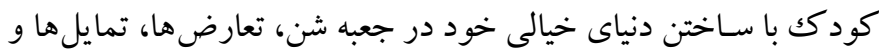
هيجانهايش را بيان مى كند (19). شـنبازىدرمانى باعث مىشـود اغلب

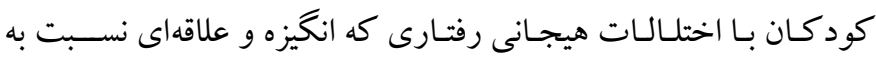

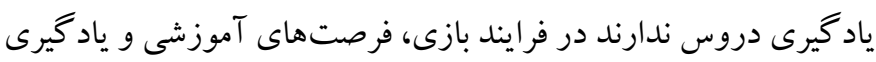

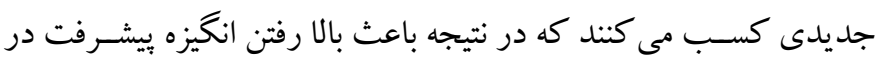

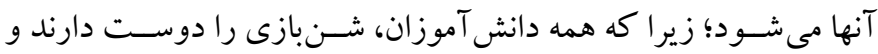
مى تو انند به طور غير مستقيم به ياد گيرى مطالب درسى بيردازند. 
تشكر و قدردانى: اين مطالعه به صـورت مسـتقل اجرا شــه اسـت و حاصـل

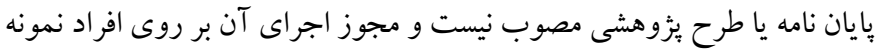

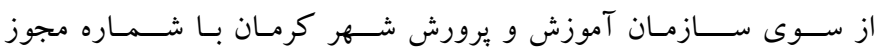
19FYA

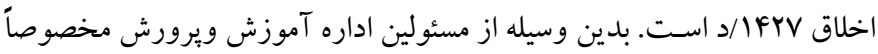

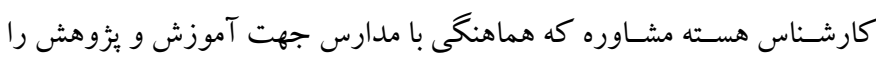

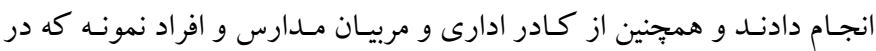
اجراى اين طرح به ما كمك كردند، تشكر و قدردانى مى وشود. تضاد منافع: در اين يزوهش هيج گُنه تعارض منافع توسط نويسند گان گزارش نشده است.
تعميم دهى يافته ها بيفز ايد. همجِنين بيشــهاد مىشـود به مقايسـه اثربخشى اين مداخله با ساير مداخلات روانشناختى در سطح كود كك يرداخته شود تا اندازه اثر اين شيوه مداخله مورد بررسى دقيق قرار گيرد. بر اساس نتايج

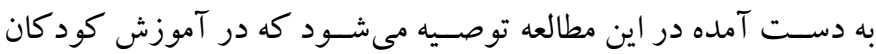
دوره ابتدايى، از بازى به ويزه شــنبازىدرمانى در برنامههاى درسـى و

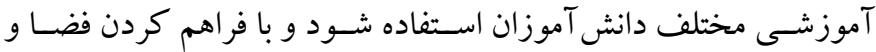
امكان دسـترسى دانش آموزان به شـنبازى، از ظرفيتهاى اين روش درد درمان اختلالات هيجانى رفتارى مانند اضطراب دانش آموزان اقدام شود.

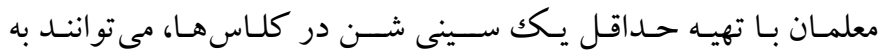
دســورزى و تخليه انرزى منفى دانش آموزان بيردازند. مديران مدارس

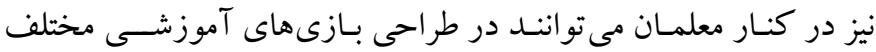

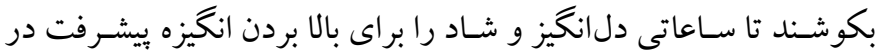
دانش آموزان ايجاد كنند. 


\section{References}

1. Kazemi N, Rasoulzadeh V, Mohammadi ST. Effect of positive thinking education on social anxiety and cognitive avoidance of mothers of children with specific learning disabilities. Quarterly Journal of Child Mental Health. 2019; 5(4): 148-158. [Persian]. [Link]

2. Rutter ML, Kreppner JM, O'Connor TG. Specificity and heterogeneity in children's responses to profound institutional privation. Br J Psychiatry. 2001; 179(2): 97-103. [Link]

3. Kessler RC, Berglund P, Demler O, Jin R, Merikangas $\mathrm{KR}$, Walters EE. Lifetime prevalence and age-ofonset distributions of DSM-IV disorders in the national comorbidity survey replication. Arch Gen Psychiatry. 2005; 62(6): 593-602. [Link]

4. Rahmanian M, Mohtarami S, Dehestani M. The effect of cognitive rehabilitation training on improving anxiety symptoms in children. Quarterly Journal of Child Mental Health. 2018; 5(1): 48-58. [Persian]. [Link]

5. Shokri Mirhosseini H, Alizade H, Fasrrokhi N. The impact of coping cat program on symptoms reduction in children with anxiety disorders. Quarterly Journal of Child Mental Health. 2018; 5(2): 1-13. [Persian]. [Link]

6. Khanjani Z, Peyamannia B, Hashemi T. Prediction of quality of interaction mother - child with anxiety disorders in children According to cultural characteristics of Iranian mothers. The Journal of New Thoughts on Education. 2016; 12(2): 239-260. [Persian]. [Link]

7. Merrell KW. Helping students overcome depression and anxiety, second edition: A practical guide. Edición: 2nd. New York: The Guilford Press; 2008, pp: 254-269. [Link]

8. Taylor CT, Bomyea J, Amir N. Attentional bias away from positive social information mediates the link between social anxiety and anxiety vulnerability to a social stressor. J Anxiety Disord. 2010; 24(4): $403-$ 408. [Link]

9. Connolly SD, Bernstein GA. Practice parameter for the assessment and treatment of children and adolescents with anxiety disorders. J Am Acad Child Adolesc Psychiatry. 2007; 46(2): 267-283. [Link]

10. Ginsburg GS, Becker KD, Drazdowski TK, Tein J-Y. Treating anxiety disorders in inner city schools: Results from a pilot randomized controlled trial comparing CBT and usual care. Child Youth Care Forum. 2012; 41(1): 1-19. [Link]
11. Fergusson DM, Horwood LJ. Vulnerability to life events exposure. Psychol Med. 1987; 17(3): 739-749. [Link]

12. Tehranizadeh M, Dadsetan P, R. Tabatabaee K, Azad Fallah P, Fathi Ashtiani A. Effectiveness of the coping cat therapy program in decreasing internalized symptoms of Iranian children. Journal of Developmental Psychology: Iranian Psychologists. 2011; 7(28): 313-322. [Persian]. [Link]

13. Slavin RE. Developmental and motivational perspectives on cooperative learning: A reconciliation. Child Dev. 1987; 58(5): 1161-1167. [Link]

14. Ghadampour E, Shahbazirad A, Haghighi Kermanshahi M, Mohammadi F, Naseri N. The effects of sand play therapy in reduction of impulsivity and attention deficit in boys with ADHD. Quarterly Journal of Child Mental Health. 2018; 5(2): 36-46. [Persian]. [Link]

15. Zhang W, Zhang R, Haslam DR, Jiang Z. The effects of restricted group sandplay therapy on interpersonal issues of college students in China. Arts Psychother. 2011; 38(4): 281-289. [Link]

16. Allan J, Berry P. Sandplay. Elementary School Guidance \& Counseling. 1987; 21(4): 300-306. [Link]

17. Mofidi F. Margaret Lowenfeld, inventor of sand therapy. Journal of Preschool Education Development. 2010; 27: 8-9. [Persian]. [Link]

18. Cunningham L. What is Sandplay Therapy? Journal of Sandplay Therapy. 1997; 6(1): 10-13. [Link]

19. Grubbs GA. A comparative analysis of the sandplay process of sexually abused and nonclinical children. Arts Psychother. 1995; 22(5): 429-446. [Link]

20. Hunter LB. Images of resiliency: Troubled children create healing stories in the language of sandplay. Palm Beach, Fla: Behavioral Communications Institute; 1998. [Link]

21. Sharifi Daramadi P, Fath Abadi R, Bakhtiarvand M, Ahmadi A. Effectiveness of sand play therapy on challenging behaviors and anxiety in children with high-functioning autism disorder. Empowering Exceptional Children. 2019; 10(1): 1-14. [Persian]. [Link]

22. Shamsi pour A, Solgi R, Rozbahani M, Babaee Amirir N, Darabi B. Effectiveness of of play therapy (with sand play approach) in children with PTSD. Journal of Exceptional Children. 2019; 18(4): 55-66. [Persian]. [Link]

23. Seyyedi SM, Makvand Hosseini S, Kiyan Ersi F. The effect of sand play therapy in reducing anxiety in 
primary school children by using observer software. Journal of Modern Psychological Researches. 2013; 8(30): 55-76. [Persian]. [Link]

24. Bazmi T, Nersi M. The effect of play therapy' techniques on reduction of anxiety and increasing of positive feeling as well as general adjustment level in children suffering blood cancer in Tehran city. Journal of Psychological Studies. 2013; 8(4): 107-130. [Persian]. [Link]

25. Maeng J, Jang M. The effects of Sandplay therapy on the anxiety, self-esteem, and sociality of college students with blindness. Journal of Symbols \& Sandplay Therapy. 2014; 5(1): 14-22. [Link]

26. Cao H, Shan W, Xu Y, Xu R. Eastern sandplay as a safe container for a combined intervention for a child with Asperger syndrome: A case study. Arts Psychother. 2013; 40(1): 134-142. [Link]

27. Goss S, Campbell MA. The value of sandplay as a therapeutic tool for school guidance counsellors. J Psychol Couns Sch. 2004; 14(2): 211-220. [Link]

28. Kwak HJ, Ahn UK, Lim MH. The clinical effects of school sandplay group therapy on general children with a focus on Korea child \& youth personality test. BMC Psychol. 2020; 8(1): 9. [Link]

29. Kwak HJ, An UK, Han KJ, Lim MH. The clinical effect of school sand play group counseling on child emotion and behavior. The Journal of the Korea Contents Association. 2018; 18(12): 54-61. [Link]

30. Foo M, Ancok D, Milfayetty S. The effectiveness of sandplay therapy in reducing anxiety in midlife women with generalized anxiety disorder. Journal of Sandplay Therapy. 2017; 26(2): 137-145. [Link]

31. Akimoto M. Application of sandplay therapy in braininjured elderly. Journal of Sandplay Therapy. 1995; 5: 71-83. [Link]

32. Salleh MSM, Johari KSK, Amat MI, Ayob Z. The effectiveness of sand tray therapy in addiction counseling as an intervention in increasing treatment motivation of recovering adolescents. In: Simposium Antar Bangsa Seminar dan Workshop. Redwhite Press; 2019, pp: 113-120. [Link]

33. Dortaj F. Comparing the effects of game-based and traditional teaching methods on students' learning motivation and math progress. Journal of School Psychology. 2014; 2(4): 62-80. [Persian]. [Link]

34. Zadedabbaq H, Saleh Sedghpour B, Aminifar E. The effect of a computer game on students' mathematics motivation and achievement. Journal of Technology of Education (Journal of Technology and Education). 2012; 6(3): 177-184. [Persian]. [Link]

35. Beck AT, Steer RA. The Beck anxiety inventory manual. San Antonio, TX: Psychological Corporation; 1990. [Link]

36. Kaviani H, Mousavi AS. Psychometric properties of the Persian version of Beck anxiety inventory (BAI). Tehran University Medical Journal TUMS Publications. 2008; 66(2): 136-140. [Persian]. [Link]

37. Rafiei M, Seifi A. An investigation into the reliability and validity of beck anxiety inventory among the university students. Thoughts and Behavior in Clinical Psychology. 2013; 8(27): 37-46. [Persian]. [Link]

38. Hermans HJ. A questionnaire measure of achievement motivation. J Appl Psychol. 1970; 54(4): 353-363. [Link]

39. Slade LA, Rush MC. Achievement motivation and the dynamics of task difficulty choices. J Pers Soc Psychol. 1991; 60(1): 165-172. [Link]

40. Akbari B. Validity and reliability of hermen's achievement motivation test on the Guilan's high school students. Research in Curriculum Planning. 2008; 1(16): 73-96. [Persian]. [Link]

41. Nouhi S, Hoseini M, Rokhsarizadeh H, Saburi A, Alishiri G. Progress motivation among Baqiyatallah university of medical sciences students and its relationship with academic achievement. Journal of Military Medicine. 2012; 14(3): 200-204. [Persian]. [Link]

42. Hamidi M. Educational games. Tehran: Iran Publication; 1989. [Persian]. 